\title{
Studies of Resistance to Sharka (Plum Pox) in Romanian Apricot Progenies
}

\author{
LIGIA ION ${ }^{1 *}$, MIRELA OLGA BOLOACÄ $\breve{1}^{1}$
}

${ }^{1}$ University of Agronomic Sciences and Veterinary Medicine Bucharest, 59 Marasti, Romania

\begin{abstract}
Sharka (Plum pox) is considered one of the most devastating diseases of stone fruits in terms of agronomic impact and economic importance. The response of several apricot hybrids was evaluated over the vegetative period of 2010 by visual monitoring of symptom development and by serological and molecular methods. After two cycles of study, all the replicates of 'Mari de Cenad', 'Traian' and 'Tabriz' showed sharka symptoms while the replicates of 'Stark Early Orange' and NJA 2 did not show any symptoms and were not ELISA-positive. The resistant progenitors ('Stark Early Orange', NJA17, NJA42 and NJA2) were able to transmit PPV resistance to their descendants, in agreement with previous results (DOSBA et al, 1994, MARTINEZ-GOMEZ et al, 2000; AUDERGON et al, 1994). The genetic control hypotheses for PPV resistance in apricot referenced by different authors considered the resistance allele as dominant. Romanian apricot F1 and F2 progenies evaluated were classified into two groups: susceptible to PPV and resistant to PPV. After that the most important genotypes were grafted onto infected GF 305 (considered as indicator for PPV) in greenhouse conditions. The final step is the introduction and development of the marker-assisted selection (MAS) in PPV resistance F1 and F2 progenies in apricot Romanian genotypes. DNA was isolated from all hybrids and parent genotypes. These samples will be used to implement the molecular markers for identification of genes linked to plant response to PPV infection.
\end{abstract}

Keywords Virus, cultivars, rootstocks, susceptible, detection, markers.

To cite this article: ION L, BOLOACĂ MO. Studies of Resistance to Sharka (Plum Pox) in Romanian Apricot Progenies. Rom Biotechnol Lett. 2021; 26(2): 2428-2433. DOI: $10.25083 / \mathrm{rbl} / 26.2 / 2428.2433$

*Corresponding author: LIGIA ION, University of Agronomical Sciences and Veterinary Medicine Bucharest, Faculty of Biotechnologies, 59, Mărăsti Blvd, 011464, Romania

E-mail: $\underline{\text { ionnagyligia@yahoo.fr }}$ 


\section{Introduction}

Apricot is the third most important species among the stone fruit crops with world production of approximately 2.69 million tons (FAO 2004). However, since the late 1980s, the Sharka disease has become a serious threat for this species (DESVIGNES et al, 1999). It is caused by the Plum pox virus (PPV), which is included in the genus Potyvirus. In Europe, PPV is the most important virus affecting Prunus fruit crops and the most limiting factor for apricot cultivation in terms of economics (LLÁCER AND CAMBRA, 1998).

The virus is naturally transmitted by aphids in a nonpersistent way when migrating between plants and making test probes. Chemical control of the aphid vector is inefficient (ZAGRAI et al, 2005). In addition, human activity is responsible for long-distance spread by vegetative multiplication of infected rootstocks or cultivars (ZAGRAI et al, 2009). Owing to this mode of diffusion, its complete eradication by conventional methods is quite impossible. Countries with a low incidence of disease limit PPV spread by removing infected trees and through the use of certified virus-free materials (RAVELONANDRO et al, 2000). For others, the only way to solve this problem is to cultivate resistant varieties (DICENTA, 2000; AUDERGON et al, 1994).

Several programs aiming at breeding PPV resistant or partially resistant apricot cultivars are underway in Europe (POLÁK, 1994; RANKOVIĆ et al, 1994; HARTMANN, 1998; 2002; JAKUBOWSKI, 1998; JACOB, 2002).
The majority of existing apricot cultivars show different levels of susceptibility to PPV. The Romanian cultivars 'Mari de Cenad', 'Traian' and 'Tabriz' are partially resistant cultivars: only few symptoms are observed on leaves and virus particles are present in plant tissues at low concentration (DOSBA et al, 1994; ZAWADZKA et al, 1994). In Romania, in 2008, a breeding program was initiated using the Romanian cultivars 'Mari de Cenad', 'Traian', 'Tabriz', 'Viceroy', 'Kesth Pshor' and different sources of resistance like the varieties 'Stark Early Orange' (SEO), 'New Jersey America' (NJA 2, NJA 42, NJA 17).

The goals of the work presented in this communication are i) the identification of natural source(s) of resistance to $\mathrm{PPV}$, ii) to introduce this resistance into commercial cultivars well adapted in our country, and iii) the implementation of marker-assisted selection (MAS), based on markers tightly associated with resistance, to substantially streamline the breeding process.

\section{Materials and Methods}

\section{Plant materials}

New apricot F2 progenies were used from crosses between PPV resistant genitors the north American New Jersey (NJA2, NJA 17, NJA 42) and 'Stark Early Orange' (SEO) (MEHLENBACKER et al, 1986) and local varieties ('Viceroy', 'Mari de Cenad', 'Traian', 'Tabriz' etc.). Nine hybrids combinations of apricot produced at the Fruit Research Station, Constanta, Romania are presented in Table 1.

Table 1. Hybrid apricot combinations performed

\begin{tabular}{|c|c|c|c|}
\hline Combination & Name of population & Genitors & $\begin{array}{c}\text { Number } \\
\text { of ind. }\end{array}$ \\
\hline $\mathrm{C} 1$ & VT 92.02.52 & NJA $17 \times$ R9 P 53 ( Viceroy $\times$ NJA2) & 5 \\
\hline $\mathrm{C} 2$ & VT 92.01.05 & NJA $17 \times$ R9 P $54($ Viceroy $\times$ NJA2) & 5 \\
\hline $\mathrm{C} 3$ & VT 92.02.95 & NJA $17 \times$ R9 P $56($ Viceroy $\times$ NJA2) & 5 \\
\hline $\mathrm{C} 4$ & VT 92.02.91 & NJA $17 \times$ R9 P 55 ( Viceroy $\times$ NJA2) & 5 \\
\hline $\mathrm{C} 5$ & Proba 56 & R10 P79 ( Viceroy $\times$ NJA2) $\times$ Tabriz & 5 \\
\hline C6 & Proba 36 & R10 P79 $\times$ Traian & 5 \\
\hline $\mathrm{C} 7$ & V5 - VT 30/40 & Mari de Cenari $\times($ SEO $)$ & 5 \\
\hline $\mathrm{C} 8$ & V6 - VT 12/13 & MOONGOLD $\times$ NJA 42 & 5 \\
\hline C9 & VT 4/73 & VIVAGOLD $\times$ NJA 42 & 5 \\
\hline
\end{tabular}

\section{PPV isolate and inoculation}

For this work was used one isolate of each PPV-D and PPV-M strain. PPV-D is less aggressive. The PPV isolates come from the collection of the Fruit Research Station, Bistrita (Romania) and were isolated from plum trees.
The apricot hybrid budsticks were grafted (by chip budding) onto GF 305 rootstocks previously inoculated with PPV which was used like susceptible rootstock in greenhouse conditions. Two repetitions of five plants of each combination per strains were tested with PPV (Figure 1). 


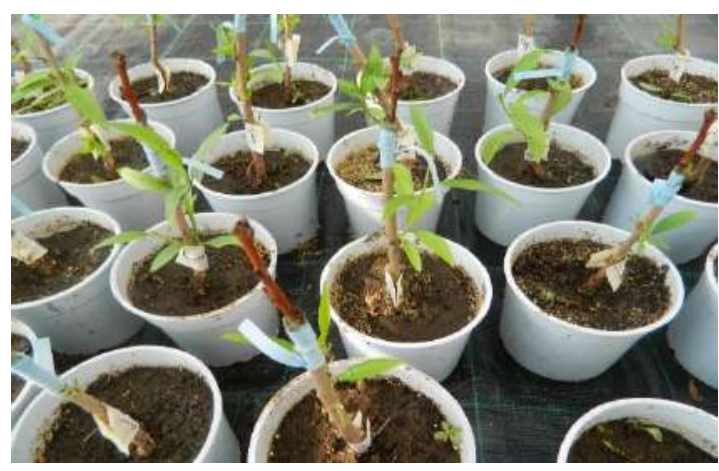

Figure 1

For phenotyping, Romanian F1 and F2 progenies were tested by artificial inoculation and verified by ELISA and RT-PCR.

Data issued from the phenotyping were compared to genotyping data that were generated by IVIA (Spain).

Presence of PPV in both the scion and the rootstock of infected plants were examined by serological ELISA tests, three times during the years 2010 and 2011.

For testing, leaf samples were collected from the base half of the plants and from the top half of the plants developed from scion buds. In the case of shoots derived from the inoculum buds, leaves were also collected to confirm the presence of PPV.

\section{DNA extraction}

DNA extraction Genomic DNA was isolated from fresh apricot leaves using the hexadecyltrimethylammonium bromide (CTAB) protocol described by Eldredge et al. (1992). DNA concentrations were measured with a minifluorimeter (TKO100, Hoefer Scientific). Working solutions of genomic DNA at $100 \mathrm{ng} / \mu \mathrm{l}$ in TE buffer ( $\mathrm{pH}$ 8.0) were prepared for SSR (Simple sequence repeat) analysis.

\section{Serological method - ELISA of detections}

Serological tests were performed by DAS-ELISA (Double Antibody Sandwich-Enzyme Linked Immunosorbent Assay), using polyclonalantibodies according to the manufacturer (Bioreba).

After each cycle of symptom observation, one Elisa test was performed to assess the presence or absence of the virus. In asymptomatic plants, 5 leaves per genotype were picked at random, whereas in the symptomatic ones, the leaves showing symptoms were chosen. Absorbance was determined at $405 \mathrm{~nm}$ after 60-min substrate incubation. The samples with optical densities double than of the healthy control were considered Elisa positive. Individuals showing symptoms and positive ELISA reaction were considered susceptible. The plants showing no symptoms and ELISA negative during two consecutive vegetative cycles were considered resistant.

Leaves were grinded in extraction buffer (AFT 0,2\% + Dieca $2 \%+$ PVP - 10) were and placed in ELISA plate previously incubated with polyclonal immunoglobulins conjugate (anti-PPV). They were then placed at $4^{\circ} \mathrm{C}$ for $16 \mathrm{~h}$. After 3 washes ( with AFT-Tween) we added $200 \mu \mathrm{l}$ of specific monoclonal PPV antibodies and incubated at $37^{\circ} \mathrm{C}$ for $2 \mathrm{~h}$. The last step was the application of immunoglobulins conjugated with alkaline phosphatase 1:1000 $(200 \mu \mathrm{I})$ and incubated for $2 \mathrm{~h}$ at $37^{\circ} \mathrm{C}$. Scoring was made at $405 \mathrm{~nm}$ considering the positive values exceeding twice the value of negative test reading (CAMBRA et al, 1994).

\section{Molecular detection}

Was performed by RT-PCR (Reverse TranscriptionPolymerase Chain Reaction) using a primer pair (P1/P2) that amplifies a $243 \mathrm{bp}$ fragment located at the C-terminus of the PPV CP gene (WETZEL et al, 1991). PPV was trapped with PPV-polyclonal antibodies adsorbed on an Eppendorf micro tube. Enhanced Avian kit provided by Sigma was used for RT-PCR. The thermal cycling scheme used was the following: RT $-30 \mathrm{~min}$ at $50^{\circ} \mathrm{C}$, denaturation / RT inactivation $-2 \mathrm{~min}$ at $94^{\circ} \mathrm{C}$ followed by 35 cycles: template denaturation $-30 \mathrm{~s}$ at $94^{\circ} \mathrm{C}$, primer annealing $-45 \mathrm{~s}$ at $61^{\circ} \mathrm{C}$ and DNA elongation $-60 \mathrm{~s}$ at $72^{\circ} \mathrm{C}$. Following to the last cycle, amplified DNA was elongated for $10 \mathrm{~min}$ at $72^{\circ} \mathrm{C}$. An aliquot of the amplified products $(10 \mu \mathrm{l})$ was fractionated onto $1.5 \%$ agarose gel electrophoresis in 1x TBE buffer. Bands were visualized by ethidiumbromide staining under UV light.

\section{Results and Discussions}

The infection process was different for various plant individuals; for some plants, the presence of PPV was detected after the first dormancy period while for some others,

PPV was detected in the $3^{\text {rd }}$ period. Some remained negative.

Serological tests were performed by DAS-ELISA (Double Antibody Sandwich-Enzyme Linked Immunosorbent Assay), using polyclonal antibodies according to the manufacturer (Bioreba).

In artificial infection conditions in the greenhouse, the results presented in Figure 2 (top of ELISA plate) shows 
that samples belonging to susceptible GF 305 rootstock were found to be positive compared with most apricot samples (bottom of ELISA plate) even if they were collected from the same plant. This means that the virus is able to infect susceptible peach rootstock but not the apricot genotypes such as V3P16, V2P18, V4 P14.

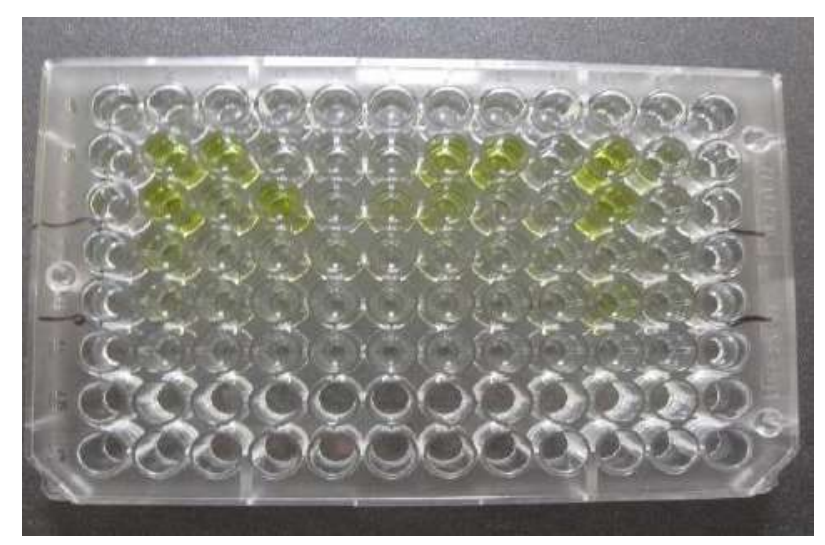

Figure 2

These potential PPV resistant individuals didn't show any visible symptoms on leaves and were thus tested by molecular techniques to confirm the absence to sharka.

Results concerning the molecular detection performed by RT-PCR (Reverse Transcription-Polymerase Chain Reaction) using a primer pair (P1/P2) that amplifies a 243 bp fragment located at the C-terminus of the PPV CP gene proved, that some apricot hybrid genotypes that were found to be ELISA negative, were eventually found PPV infected after molecular testing (see V2P18). Indeed the virus is present and symptoms appear on the fruits (Table 2).

Table 2. Phenotyping Romanian apricot progenies F1 and F2 in artificial infection conditions for resistance/tolerance to PPV; by visual inspection and ELISA and RT-PCR analysis.

\begin{tabular}{|c|c|c|c|c|c|c|c|c|}
\hline \multirow{2}{*}{$\begin{array}{c}\text { Short } \\
\text { name of } \\
\text { progeny }\end{array}$} & \multirow[t]{2}{*}{ Cross } & \multirow[t]{2}{*}{ Variants } & \multicolumn{4}{|c|}{ GF 305} & \multicolumn{2}{|c|}{ Apricot hybrids } \\
\hline & & & $\begin{array}{c}\text { PPV } \\
\text { symptoms } \\
\text { intensity } \\
\end{array}$ & $\begin{array}{l}\text { DASI-ELISA } \\
(\mathrm{DO}=405 \mathrm{~nm})\end{array}$ & $\begin{array}{l}\text { RT- } \\
\text { PCR }\end{array}$ & $\begin{array}{c}\text { PPV } \\
\text { symptoms } \\
\text { intensity } \\
\end{array}$ & $\begin{array}{l}\text { DASI-ELISA } \\
(\mathrm{DO}=405 \mathrm{~nm})\end{array}$ & $\begin{array}{l}\text { RT- } \\
\text { PCR }\end{array}$ \\
\hline $\mathrm{C} 1$ & $\begin{array}{c}\text { VT } 92.02 .52-\text { NJA } 17 * \text { (female) } \\
\text { x R9 [ } 53 \text { (male) (Viceroy x } \\
\text { NJA2*) }\end{array}$ & V3P16 & + & + & + & - & - & - \\
\hline \multirow[t]{3}{*}{$\mathrm{C} 2$} & VT 92.01.05-NJA 17* X R9 P & V2P18 & + & + & + & - & - & - \\
\hline & $53($ Viceroy x NJA2*) & V4P18 & + & + & + & - & - & - \\
\hline & & V6P20 & + & + & + & - & + & + \\
\hline $\mathrm{C} 3$ & $\begin{array}{c}\text { VT } 92.02 .95 \text { - NJA } 17 * \text { X R9 P } \\
53 \text { (Viceroy x NJA2*) }\end{array}$ & V4P19 & + & + & + & - & + & + \\
\hline $\mathrm{C} 4$ & $\begin{array}{c}\text { VT } 92.02 .91-\text { NJA } 17 * \text { X R9 P } \\
53(\text { Viceroy x NJA2*) }\end{array}$ & V2P14 & + & + & + & - & - & - \\
\hline $\mathrm{C} 5$ & $\begin{array}{c}\text { R10 P79 (Viceroy x NJA2*) X } \\
\text { Tabriz }\end{array}$ & V4C5 & ++ & ++ & + & + & + & + \\
\hline C6 & R10 P79 X Traian* & V5P19 & + & + & + & - & - & - \\
\hline \multirow[t]{8}{*}{$\mathrm{C} 7$} & V5 - VT 30/40 Mari de Cenad x & V1P19 & ++ & ++ & + & + & + & - \\
\hline & $(\mathrm{SEO} *)$ & V2P16; & + & + & + & - & - & - \\
\hline & & V2P18 & + & + & + & - & + & + \\
\hline & & V3P18 & ++ & + & + & ++ & + & + \\
\hline & & V4P19 & + & + & + & - & - & - \\
\hline & & V5P18 & + & + & + & - & - & - \\
\hline & & V6P16; & + & + & + & - & - & - \\
\hline & & V6P18 & + & + & + & + & + & + \\
\hline \multirow[t]{2}{*}{$\mathrm{C} 8$} & V6 - VT 12/13 - MOONGOLD & V2P17 & + & + & + & - & - & - \\
\hline & $\mathrm{X} \mathrm{NJA} 42 *$ & V4P16 & + & + & + & + & - & - \\
\hline C9 & $\begin{array}{c}\text { VT } 4 / 73 \text { - VIVAGOLD X NJA } \\
42 *\end{array}$ & V3P20 & + & + & + & - & - & - \\
\hline
\end{tabular}


While the genetic determinism of the resistance to PPV is still questioned (one or two or three genes, dominant versus recessive), we observed that an important number of hybrids like: V3P16, V4P18, V2P14, V2P16, V4P19, V1P19, V5P18, V4P19, V2P17, V4P16, V3P20 proved to be clearly resistant to artificial PPV infection (Table 2).

We have isolated the DNA for the parents and for Romanian hybrids.
Results concerning the phenotyping were in concordance with the results of genotyping (results performed at IVIA, Spain). Among the apricot hybrids already phenotyped, several of them were resistant to PPV (Table 3).

Romanian apricot $\mathrm{F} 1$ and $\mathrm{F} 2$ progenies were classified into two groups: susceptible to PPV and resistant to PPV.

Table 3. Validation of the PGS marker in Romanian apricot populations

\begin{tabular}{|c|c|c|c|c|}
\hline $\begin{array}{l}\text { Number of } \\
\text { Individuals }\end{array}$ & Name of individuals & PGS 1,21 & PGS 1,252 & \\
\hline $1+$ parent & NJA42 & $199 / 239$ & $90 / 92$ & resistant \\
\hline $2+$ parent & JT10/79 & $199 / 239$ & $92 / 92$ & resistant \\
\hline $3+$ parent & Moongold & $193 / 215$ & $92 / 122$ & recombinant \\
\hline $4+$ parent & NJA 17 & $193 / 239$ & $92 / 122$ & resistant \\
\hline $5+$ parent & SEO & $193 / 239$ & $92 / 122$ & resistant \\
\hline $6+$ parent & Tabriz & $193 / 213$ & $92 / 122$ & susceptible \\
\hline $7+$ parent & Kesth_phor & - & $92 / 92$ & susceptible \\
\hline $8+$ parent & Vivagold & $193 / 193$ & $122 / 122$ & susceptible \\
\hline $9+$ parent & Viceroy_603_G & $193 / 213$ & $92 / 122$ & susceptible \\
\hline $10+$ parent & Traiam & $193 / 239$ & $92 / 122$ & resistant \\
\hline 1 & C2P30V6 & $193 / 239$ & $92 / 122$ & resistant \\
\hline 2 & C3P19V4 & $193 / 239$ & $92 / 122$ & resistant \\
\hline 3 & C2P18V4 & $193 / 239$ & $92 / 122$ & resistant \\
\hline 4 & C2P18V2 & $193 / 239$ & $92 / 122$ & resistant \\
\hline 5 & C8P17V5 & $193 / 193$ & $122 / 122$ & autofecundation \\
\hline 6 & C7P18V5 & $193 / 239$ & $92 / 122$ & resistant \\
\hline 7 & C7P13V4 & $193 / 239$ & $92 / 122$ & resistant \\
\hline 8 & C1P16V3 & $193 / 239$ & $92 / 122$ & resistant \\
\hline 9 & C7P16V6 & $193 / 239$ & $92 / 122$ & resistant \\
\hline 10 & C9P20V3 & $239 / 239$ & $92 / 92$ & resistant \\
\hline 11 & C7P16V6 & $193 / 239$ & $92 / 122$ & resistant \\
\hline 12 & C2P18V4 & $193 / 239$ & $92 / 122$ & resistant \\
\hline 13 & C7P16V2 & - & $92 / 122$ & resistant \\
\hline 14 & C5C5V4 & $215 / 215$ & $92 / 92$ & susceptible \\
\hline 15 & C7P18V3 & $193 / 239$ & $92 / 122$ & resistant \\
\hline 16 & C9P19V1 & $239 / 239$ & $92 / 92$ & resistant \\
\hline 17 & C7P18V6 & $193 / 239$ & $92 / 122$ & resistant \\
\hline 18 & C8P16V4 & $193 / 193$ & no 92 & susceptible \\
\hline 19 & C7P18V2 & $193 / 239$ & $92 / 92$ & resistant \\
\hline
\end{tabular}

\section{Conclusions}

We observed a significant number of hybrids like: V3P16, V4P18, V2P14, V2P16, V4P19, V1P19, V5P18, V4P19, V2P17, V4P16, V3P20 which appear resistant to PPV. The detection of the virus was performed by serological and molecular tools.

Romanian apricot F1 and F2 progenies evaluated were initially classified into three groups: susceptible to PPV, partially resistant and resistant to PPV. After that the most important genotypes were classified as susceptible and resistant. The rootstocks and also apricots hybrids were monitored by visual inspection, ELISA, completed by RT-PCR.

Concerning the resistant apricot hybrids, results confirmed that PPV particles were translocated from the inoculated rootstock buds to apricot genotypes but the virus remained in the rootstock that showed symptoms on leaves. This indicates a possible inhibition of virus replication, in comparison with susceptible apricot hybrids where the virus is able to spread in the plant. However some of them showed no symtoms and PPV was detected only by serological and molecular tools. 
The goals at the work presented in this communication are the development and implementation of marker - assisted selection (MAS) for PPV resistance in F1 and F2 progenies in apricot Romanian breeding programmes. The first step in this direction has already been implemented by validating the Spanish molecular markers (PGS 1. 21 and PGS 1. 252) in our populations.

\section{Acknowledgments}

This study was financed by project SharCO "Sharka containment" - FP7 - Grant Agreement no 204429 funded by European Union.

\section{Conflict of Interest}

The authors have no conflict of interest to declare.

\section{References}

1. AUDERGON J.M., DOSBA F., KARAYANNIS I. and DICENTA F. 1994. Amelioration de L'abricotier pour la resistance a la sharka. Bill. OEPP/EPPO Bull. 24:741-748.

2. CAMBRA M., ASENSIO M., GORRIS M.T., GARCI'A J.A., MOYA J.J., LO’PEZ-ABELLA D., VELA C. and SANZ A. 1994. Detection of Plum pox potyvirus using monoclonal antibodies to structural and non-structural proteins. EPPO Bull. 24:569-578.

3. DECROOCQ V., SCHURDI-LEVRAUD V., WAWRZYNCZAK D., EYQUARD J.P. and LANSAC M. 2002. Transcript imaging and candidate gene strategy for the characterisation of Prunus/PPV interaction. Plant Prot. Sci. 38:112-116.

4. DESVIGNES J.C., BOYE R., CORNAGGIA D., GRASSEAU N. 1999. Virus diseases of fruit trees. Editions Centre technique interprofessionnel des fruits et legumes, Paris: 202.

5. DOSBA F., LANSAC M. and EYQUARD J.P. 1994. Plum pox resistance in Prunus. EPPO Bull. 24: 691-696.

6. DURRANT W.E., ROWLAND O., PIEDRAS P., HAMMOND-KOSACK K.E. and JONES J.D.G. 2000. CDNA-AFLP reveals a stricking overlap in race-specific resistance and wound response gene expression profiles. Plant Cell 12:963-977.

7. HARTMANN W. 1998. Strategy for breeding sharka resistant plums. Acta Hortic. 478:31-38.

8. HARTMANN W. 2002. The importance of hypersensitivity for breeding plums and prunes resistant to Plum pox virus (sharka). Acta Hortic. (The Hague) 577:33-37.

9. JACOB H.B. 2002. Breeding of plums, prunes and mirabelles in Geisenheim, Germany: breeding goals and previous realisation. Acta Hortic. (The Hague) 577:39-43.
10. JAKUBOWSKI MT. 1998. Breeding of plum cultivars in Poland. Acta Hortic. 478:151-154.

11. KEGLER H., FUCHS E., GRUNTZIG M. and SCHWARZ S. 2000. Screening of plum, peach and apricot cultivars for resistance to Plum pox potyvirus. Acta Hort. 538:397-405.

12. LLÁCER G., CAMBRA M. 1998. Thirteen years of sharka disease in Valencia, Spain. Acta Hortic. 472:379-384.

13. MARTINEZ-GOMEZ P., DICENTA F. and AUDERGON J.-M. 2000. Behaviour of apricot (Prunus armeniaca L.) cultivars in the presence of sharka (plum pox potyvirus) a review. Agronomie, 20:407-422.

14. MECHLENBACKER F., HOUGH L.P., 1986. Progress in apricot breeding in New Jersey. Acta Horticulturae 192: 167-175.

15. POLÁK J. 1994. Breeding for resistance to plum pox potyvirus in the Czech Republic. EPPO Bull. 24:781-782.

16. RANKOVIĆ M., OGA ̌̌ANOVIĆ D. and PAUNOVIĆ S. 1994. Breeding of plum cultivars resistant to sharka (plum pox) disease. Acta Hortic. (The Hague) 359:69-74.

17. RAVELONANDRO M., SCORZA R., CALLAHAN A., LEVY L., JACQUET C., MONSION, M. and DAMSTEEGT, V. 2000. The use of transgenic fruit trees as a resistance strategy for virus epidemics: the plum pox (sharka) model. Virus Res. 71:63-69.

18. SAMUELIAN S., KLEINE M., RUYTER-SPIRA C.P., KLEIN-LANKHORST R.M. and JUNG C. 2004. Cloning and functional analyses of a gene from sugar beet up-regulated upon cyst nematode infection. Plant Mol. Biol. 54:147-156.

19. WETZEL T., CANDRESSE T., RAVELOANNDRO M. and DUNEZ J. 1991. A polymerase chain reaction assay adapted to plum pox potyvirus detection. Journal of Virological Methods 33:355-365.

20. ZAGRAI I., ARDELEAN M., MAXIM A., ZAGRAI L., VLADIANU D., ISAC M., CATANA C., GABOREANU I. 2005. Studiez on the spread of Plum pox virus (PPV) in a canopy of several plum cultivars. Phytopathol. Pol. 36:123-129.

21. ZAGRAI I., ZAGRAI L., ION L. 2009. The Reponse of different Prunus genotypes to D and Rec Stains of Plum pox virus. Bulletin USAMV, no.66 (1-2) 2009 Horticulture, Print ISSN 1843-5254: Electronic ISSN 1843-5394.

22. ZAWADZKA B., ROZPARA E., GRZYB Z. and MALINOWSKI T. 1994. Susceptibility of some North American and Yugoslav plum cultivars to plum pox potyvirus in Poland. EPPO Bull. 24:767-770.

23. ZHENG X., CHEN X., ZHANG X., LIN Z., SHANG J., XU J., ZHAI W. and ZHU L. 2004. Isolation and identification of a gene in response to rice blast disease in rice. Plant Mol. Biol. 54:99-109. 